\title{
Pengembangan Usahatani Cabai Merah di Lahan Pasir Pantai Kecamatan Temon Kabupaten Kulonprogo
}

\author{
Development of Red Chilli Farming in \\ Coastal Land of Temon, Kulonprogo
}

D 01:10.18196/ agr.112

\begin{abstract}
The objective of this research is determine the profit of red chili farming coastal land, the factors that influence of red chili production and efficiency used of production factors on red chili farming on coastal land in Temon subdistrict Kulon Progo Regency. Selection of the location is used purposive method. Fourty farmer sampling were taken as simple random sampling. The analysis method is used Multiple Regression Analysis with Ordinary Least Square (OLS) method. The result showed that the income of red chili farming in coastal land is $\operatorname{Rp} 9.278 .430 / 0,38$ ha and the profit is Rp 3.094.504/0,38 ha. The production factors concists of the soil of area, number of seeds, amount of labors, manure fertilizer, dunk fertilizer,
\end{abstract}

Za chemic fertilizer, SP 36 fertilizer, NPK Mutiara fertilizer, Phonska fertilizer, Furadan insecticide, Ampligo fungicide, Anthracol fungicide, Confidor insecticide, the kind of seeds and used of mulch aggregated influences to red chili production. The production factors number of seeds, amount of labors, manure fertilizer, NPK Mutiara fertilizer, Ampligo fungicide, kind of seeds and used mulch partially influences to red chili production on coastal land. Seed applied on red chili farming on coastal land is efficient Keywords : coastal land, income, profit, efficiency

\section{PENDAHULUAN}

Lahan merupakan faktor produksi yang utama dalam usahatani. Proses alih fungsi lahan menyebabkan pemilikan lahan oleh rumah tangga petani semakin sempit. Dalam kurun waktu 1991 - 2020 diperkirakan sekitar 680.000 hektar lahan pertanian di Jawa akan berubah menjadi lahan non pertanian. Hal yang sama juga akan terjadi di luar Jawa terutama di Bali, Sumatra dan Sulawesi, sehingga dalam kurun waktu tersebut lahan pertanian berkurang seluas 807.000 hektar. Mengingat masalah tersebut, salah satu alternatif yang dapat dilakukan adalah perluasan areal pertanian ke arah lahan marjinal. Salah satu lahan marjinal yang potensial untuk dijadikan lahan pertanian adalah lahan pantai.

Lahan pantai yang telah dikembangkan menjadi lahan pertanian di Propinsi DIY tersebar di Kabupaten Bantul dan Kulon Progo. Lahan pantai di Kulon Progo sebagian besar adalah milik negara dan Paku Alam Ground, sedangkan di Bantul merupakan lahan Sultan Ground. Pemanfaatan lahan pantai di kedua daerah tersebut dapat mengatasi kehilangan tanah pertanian 1.337,7 hektar per tahun akibat konversi lahan pertanian menjadi permukiman. (Dinas Pertanian DIY, 2007).

Kabupaten Kulon Progo merupakan daerah penghasil cabai di Provinsi Daerah Istimewa Yogyakarta yang menunjukkan peningkatan produksi secara signifikan setiap tahunnya. Peningkatan luas panen cabai berturutturut sebagai berikut (Dinas Pertanian Kabupaten Kulon Progo,2008) : 
tahun 2004 (527 ha), tahun 2005 (741 ha), tahun 2006 (943 ha), tahun 2007 (931 ha), tahun 2008 (1.027 ha).

Cabai merupakan tanaman hortikultura yang dapat tumbuh di berbagai jenis tanah, salah satunya di lahan pasir pantai. Lahan dengan ciri utama bertekstur pasir, kandungan hara yang rendah, mudah tererosi oleh angin yang sangat kencang serta suhu udara yang tinggi merupakan kendala utama apabila dikembangkan untuk budidaya tanaman pangan maupun tanaman hortikultura.

Lahan diominasi oleh fraksi pasir (>95\%) sedangkan fraksi debu dan lempungnya sangat rendah menyebabkan lahan pasir pantai memiliki daya meluluskan air yang tinggi. Lahan pasir pantai dengan kandungan unsur hara yang rendah memerlukan pembenah tanah agar tercipta kondisi tanah yang mendukung untuk pertumbuhan tanaman pangan maupun tanaman hortikultura. Kendala lain yang muncul di lahan pasir pantai adalah suhu tanah yang tinggi di siang dan sore hari.

Faktor lain di lahan pasir adalah adanya angin laut yang kencang dan membawa kandungan garam laut dapat merusak daun tanaman cabai. Guna menanggulangi hal tersebut diperlukan tanaman keras atau penghalang yang berfungsi sebagai pemecah angin. Tanaman keras yang ada di sekitar lahan pertanian yakni pohon jambu mete yang memberikan dampak langsung pada tanaman yang ada sebagai pelindung untuk mengurangi suhu udara yang tinggi.

Berbagai macam kendala yang muncul di lahan pasir pantai menuntut petani menggunakan faktor produksi yang lebih baik dalam kuantitas maupun kualitas. Petani berharap dengan menggunakan faktor produksi yang lebih banyak produksi akan tinggi. Di sisi lain produksi dan harga cabai sangat tergantung pada musim. Pada musim penghujan hanya sedikit petani yang menanam cabai karena resikonya besar sehingga harga cabai di pasar cukup tinggi. Musim kemarau banyak petani yang menanam cabai akibatnya harga cabai di pasar menjadi relatif rendah. Penelitian ini bertujuan mengetahui keuntungan usahatani, faktor-faktor yang mempengaruhi produksi dan efisiensi usahatani cabai merah di lahan pasir pantai

\section{METODE PENELITIAN}

Penelitian ini dilakukan di Kecamatan Temon Kabupaten Kulonprogo dan merupakan penelitian deskriptif (deskriptif research) yang pelaksanaannya menggunakan metode survai. Penentuan lokasi penelitian menggunakan metode purposive sampling (Nazir, 2002) dengan pertimbangan Kecamatan Temon mempunyai luas panen dan produktivitas cabai yang tertinggi di Kabupaten Kulonprogo. Petani sampel berjumlah 40 orang yang diambil secara acak sederhana (simple random sampling)

Keuntungan usahatani merupakan pengurangan penerimaan total dengan biaya total (explicit dan implicit), Suratiyah (2006) Secara sistematis keuntungan dapat dirumuskan berikut :

$$
\begin{aligned}
& \pi=\mathrm{TR}-\mathrm{TC} \text { explicit }+ \text { implicit } \\
& \begin{array}{ll}
\text { Keterangan : } & \\
\pi & =\text { Profit (keuntungan) } \\
\text { TR } & =\text { Total Revenue (penerimaan) } \\
\text { TC explicit } & =\text { Total Cost explicit (biaya total eksplisit) } \\
\text { TC implicit } & =\text { Total Cost implicit (biaya total implisit) }
\end{array}
\end{aligned}
$$

Untuk menganalisis faktor-faktor yang mempengaruhi produksi digunakan fungsi produksi Cobb - Douglass. Selanjutnya dengan model Ordinary Least Square (OLS) dari analisis regresi akan diperoleh koefisien regresi dari masing-masing faktor produksi (Gujarati, 2006). Untuk mengetahui pengaruh faktor produksi secara bersamasama digunakan uji $\mathrm{F}$, sedangkan pengaruh masingmasing faktor produksi digunakan uji t. Penggunaan faktor produksi dikatakan efisien jika perbandingan antara nilai produk marginal (NPM) untuk suatu input (Xi) dengan nilai harga input (Pxi) tersebut sama dengan satu (NPM/P=1), Soekartawi (2003)

\section{HASIL DAN PEMBAHASAN PENDAPATAN DAN KEUNTUNGAN USAHATANI CABAI MERAH}

Biaya produksi digolongkan menjadi dua macam yakni biaya implisit merupakan biaya yang tidak dikeluarkan oleh petani secara riil dan biaya eksplisit adalah biaya yang secara nyata dikeluarkan oleh petani dalam satu proses produksi.

Berdasarkan tabel 1, diketahui bahwa biaya eksplisit lebih besar dari biaya imlpisitnya. Biaya tenaga kerja ada dua macam, yakni biaya tenaga kerja eksplisit dan biaya tenaga kerja implisit. Biaya tenaga kerjadalam keluarga (implisit) tidak jauh berbeda dengan biaya tenaga kerja luar keluarga (eksplisit) karena dalam perawatan (terutama penyiraman) dilakukan setiap hari dan membutuhkan cukup banyak tenaga kerja yang dicurahkan dilakukan sendiri. Biaya sewa lahan ada dua 
TABEL I. BIAYA USAHATANI CABAI MERAH DI LAHAN PASIR PANTAI KECAMATAN TEMON

\begin{tabular}{llllll}
\hline \multirow{2}{*}{ No } & \multirow{2}{*}{ Uraian } & Biaya (Rp) & $\begin{array}{l}\text { Biaya } \\
\text { Total (Rp) }\end{array}$ & $\begin{array}{l}\text { Persentase } \\
\text { (\%) }\end{array}$ \\
\cline { 3 - 4 } & Eksplisit & Implisit & 448.450 & 2,36 \\
\hline 1 & Biaya Penyusutan Alat & 448.450 & & 5.153 .700 & 27,16 \\
2 & Biaya Saprodi & 5.153 .700 & & 1.896 .244 & 9,99 \\
3 & Biaya Lain-lain & 1.896 .244 & & 9.889 .050 & 52,13 \\
4 & Biaya Tenaga Kerja & 5.182 .500 & 4.706 .550 & 26.437 .5 & 0,13 \\
5 & PBB & $26.43,5$ & & 786.875 & 4,14 \\
6 & Biaya Sewa lahan & 77.500 & 709.375 & $768.001,12$ & 4,04 \\
7 & Bunga modal sendiri & & $768.001,12$ & $7.968 .757,37$ & 100 \\
\hline & Jumlah & $12.784 .831,25$ & $6.183 .926,12$ & 18.968 .72 & \\
\hline
\end{tabular}

tabel 2. Pendapatan dan keuntungan Petani cabal merah di lahan pantal keCamatan temon Per 0,38 Ha

\begin{tabular}{lll}
\hline No & Uraian & Nilai (Rp) \\
\hline 1 & Produksi $(\mathrm{kg})$ & $2.230,68$ \\
2 & Harga $(\mathrm{Rp} / \mathrm{kg})$ & 9891 \\
3 & Penerimaan $(\mathrm{Rp})$ & 22.063 .261 \\
4 & Biaya Eksplisit (Rp) & 12.784 .831 \\
5 & Biaya Implisit (Rp) & 6.183 .926 \\
6 & Pendapatan (Rp) & 9.278 .430 \\
7 & Keuntungan (Rp) & 3.094 .504 \\
\hline
\end{tabular}

macam yakni biaya sewa lahan yang masuk kedalam biaya eksplisit dan biaya sewa lahan yang termasuk biaya implisit. Biaya sewa lahan ekslipisit merupakan biaya yang dikeluarkan oleh petani yang menyewa lahan untuk usahatani cabai merah, baik yang menyewa seluruhnya atau sebagian.

Berdasarkan tabel 2 dapat diketahui bahwa produksi cabai merah di lahan pantai untuk luas lahan 0,38 ha sebesar 2.230,68 kg, yang diperoleh dari 10 sampai 20 kali panen. Selama musim panen harga cabai merah berfluktuasi sekali berkisar antara $\mathrm{Rp} 3.000$,- sampai $\mathrm{Rp}$ 23.000,-. Pendapatan total yang diperoleh selama satu musim tanam (6 bulan) sebesar Rp 9.278.430,-, jadi tiap bulan rata-rata petani memperoleh pendapatan lebih dari Rp 1.500.000,-.

\section{FAKTOR-FAKTOR YANG MEMPENGARUHI PRODUKSI USAHATANI CABAI MERAH}

Untuk mengetahui faktor-faktor yang mempengaruhi produksi usahatani cabai merah di lahan pantai digunakan analisis regresi berganda dengan model Ordinary Least Square. Produksi cabai yang dianalisis adalah produksi pada saat penelitian dilaksanakan yaitu pada musim tanam 1 .

Hasil uji ketetapan model berdasarkan nilai koefisien determinasi (R2) sebesar 0,961 berarti 96,1\% variasi variabel dependen (produksi cabai merah) dapat dijelaskan oleh variabel independent yang dimasukkan kedalam model (luas lahan, tenaga kerja, pupuk dasar, pupuk kimia, obat-obatan, benih, intensitas penyiraman dan jenis benih) sedangkan sisanya sebesar 3,9\% 
TABEL 3. ANALISIS REGRESI FAKTOR-FAKTOR YANG MEMPENGARUHI PRODUKSI CABAI MERAH DI LAHAN PASIR PANTAI KECAMATAN TEMON TAHUN 2012

\begin{tabular}{|c|c|c|c|c|}
\hline No & Variabel & $\begin{array}{l}\text { Koefisien } \\
\text { Regresi }\end{array}$ & t-hitung & Signifikan \\
\hline 1. & Konstanta & 2,38 & 1,2 & 0,23 \\
\hline 2. & Luas Lahan (ha) & $-0,15$ & $-0,43$ & 0,67 \\
\hline 3. & Benih (bungkus) & $0,25^{*}$ & 1,79 & 0,08 \\
\hline 4. & Tenaga Kerja (HKO) & $1,02^{* * *}$ & 4,11 & 0,00 \\
\hline 5. & Pupuk Kotoran Ayam (rit) & $-0,04^{* * *}$ & $-3,56$ & 0,00 \\
\hline 6. & Pupuk Kotoran Sapi (rit) & 0,08 & 0,00 & 0,99 \\
\hline 7. & Pupuk ZA (kg) & $-0,01$ & $-1,24$ & 0,22 \\
\hline 8. & Pupuk Phonska (kg) & $-0,24$ & $-1,67$ & 0,10 \\
\hline 9. & Pupuk SP36 (kg) & 0,00 & 0,32 & 0,75 \\
\hline 10. & Pupuk NPK Mutiara (kg) & $-0,02^{*}$ & $-1,98$ & 0,05 \\
\hline 11. & Insektisida Furadan (I) & 0,71 & 1,49 & 0,15 \\
\hline 12. & Fungisida Antracol (I) & $-0,13$ & $-0,49$ & 0,62 \\
\hline 13. & Insektisida Abamectin (I) & $-0,07$ & 0,29 & 0,77 \\
\hline 14. & Fungisida Ampligo (I) & $-0,03^{*}$ & $-1,87$ & 0,07 \\
\hline 15. & Insektisida Confidor (I) & 0,14 & 1,07 & 0,29 \\
\hline 16. & Jenis Benih & $-0,01^{*}$ & $-2,03$ & 0,05 \\
\hline \multirow[t]{3}{*}{17.} & Penggunaan Mulsa & $0,01^{* *}$ & 2,28 & 0,03 \\
\hline & R Squared & 961 & & \\
\hline & F hitung & 35,370 & & \\
\hline & $\begin{aligned} \text { KETERANGAN : } & { }^{*}: \text { sig } \\
& { }^{* *}: \text { sig } \\
& { }^{* * *}: \text { sig }\end{aligned}$ & $\begin{array}{l}\text { si pada á 0,1 } \\
\text { si pada á 0,05 } \\
\text { i pada á 0,01 }\end{array}$ & & \\
\hline
\end{tabular}

dijelaskan oleh faktor-faktor lain yang tidak dimasukkkan dalam model misalnya cara pemupukan, kualitas lahan dan kualitas benih.

Untuk menguji pengaruh dari variabel independen secara simultan terhadap variabel dependen digunakan uji F. Berdasarkan hasil analisis, menunjukkan bahwa Fhitung > Ftabel pada tingkat kepercayaan 99\%. Berarti produksi cabai merah dipengaruhi secara simultan oleh variabel independent (produksi cabai merah) dipengaruhi oleh luas lahan, benih, tenaga kerja, pupuk kotoran ayam, pupuk kotoran sapi, pupuk ZA, pupuk Phonska, pupuk SP36, pupuk NPK Mutiara, insektisida Furadan, Abamectin \& Confidor, fungisida Antracol \& Ampligo, jenis benih dan penggunaan mulsa diterima.
Berdasarkan uji signifikasi secara parsial, diketahui bahwa terdapat tujuh variabel yang berpengaruh signifikan terhadap produksi cabai merah yaitu benih, tenaga kerja, pupuk kotoran ayam, pupuk NPK Mutiara, Fungisida Ampligo, Jenis Benih dan Penggunaan Mulsa.

Nilai koefisien regresi benih sebesar 0,254 dan signifikan pada tingkat kepercayaan $90 \%$, artinya setiap penambahan penggunaan benih $1 \%$ dan faktor lain tetap akan meningkatkan produksi cabai merah sebesar $0,254 \%$. Hal ini menunjukkan semakin banyak benih yang digunakan dalam usahatani cabai merah, maka produksi yang dihasilkan semakin besar. Sebelum penanaman, petani melakukan persemaian terlebih dulu. Petani membuat persemaian sendiri menggunakan media 
tanah yang dicampur dengan kotoran sapi, dengan perbandingan 1:7, media tersebut dimasukkan dalam plastik polybag. Benih dimasukkan ke dalam media tanam, setiap plastik polybag berisi satu benih. Pembenihan membutuhkan waktu kurang lebih selama 25-30 hari dan bibit siap ditanam. Petani cabai lahan pantai di Kecamatan Temon menggunakan jarak tanam $40 \mathrm{x} 40 \mathrm{~cm}$. Benih yang digunakan petani ada tiga jenis yaitu Heliks, Lado dan Kiyo.

Tenaga kerja mempunyai koefisien regresi sebesar 1,029 dan signifikan pada tingkat kepercayaan 99\%. Artinya setiap penambahan penggunaan tenaga kerja sebesar $1 \%$ akan menambah produksi cabai merah sebanyak $1,029 \%$, dengan faktor lain tetap. Tenaga kerja dibutuhkan mulai dari proses pengolahan lahan, penyemprotan, penyiraman dan panen. Kurangnya tenaga kerja dapat menghambat proses produksi cabai merah. Sebagai contoh pada proses penyiraman yang harus dilakukan setiap hari, jika kekurangan tenaga kerja penyiraman dilanjutkan hari berikutnya dan akibatnya tanaman cabai menjadi layu, ada kemungkinan tanaman mati

Nilai koefisien regresi pupuk kotoran ayam sebesar 0,049 dan signifikan pada tingkat kesalahan 1\% artinya apabila ada penambahan penggunaan $1 \%$ pupuk kotoran ayam dan faktor lain tetap maka produksi cabai akan berkurang sebesar 0,049 \%. Penggunaan pupuk kotoran ayam sebagai bahan pembenah atau penyubur tanah di lahan pasir pantai dan tidak akan menampakkan hasil secara langsung atau instant. Penggunaan pembenah tanah menggunakan pupuk kandang kotoran ayam berpengaruh meningkatakan hara makro tersedia pada pasir pantai musim hujan, sehingga dapat menyuburkan tanaman cabai (Purwantono, 2012)

Koefisien regresi pupuk NPK sebesar -0,024 berpengaruh secara nyata pada tingkat kepercayaan 90\% artinya apabila ada penambahan penggunaan $1 \%$ pupuk NPK, maka produksi cabai akan berkurang sebesar 0,042 $\%$. Hal ini menunjukkan bahwa penggunaan pupuk NPK sudah berlebih atau kebutuhan unsur N, P dan K sudah terpenuhi dari pupuk lain, misalnya dari pupuk ZA, SP36 atau pupuk kandang.

Nilai koefisien regresi fungisida Ampligo sebesar 0,032 signifikan pada á 0,1 artinya apabila ada penambahan penggunaan 1\% pestisida Ampligo, maka produksi cabai akan berkurang sebesar 0,032\%. Penggunaan fungisida Ampligo disesuaikan dengan tingkat serangan hama. Petani tidak hanya menggunakan satu macam pestisida, beberapa pestisida yang digunakan petani antara lain insektisida Furadan, Abamectin, Confidor dan fungisida Antracol.

Koefisien regresi jenis benih yang dipakai sebesar 0,012 dan signifikan pada á $=0,1$ artinya penggunaan benih jenis Helix produksinya lebih rendah dibandingkan benih Lado maupun Kiyo. Padahal menurut responden, benih cabai jenis Helix daya perkecambahannya lebih baik dibandingkan dengan dua jenis lainnya.

Nilai Jenis mulsa koefisien regresi sebesar 0,019 dan signifikan pada tingkat kepercayaan 95\%, hal ini menunjukkan produksi cabai merah yang menggunakan mulsa plastik perak hitam lebih tinggi dibandingkan menggunakan mulsa jerami. Mulsa plastik mempunyai keuntungan dapat dipakai selama 2 musim tanam, meminimalisir penguapan dan menekan pertumbuhan tanaman pengganggu (Rukmana,1996). Mulsa jerami memiliki keunggulan dapat sekaligus dijadikan pupuk organik. Petani cenderung memilih menggunakan mulsa jerami karena lebih murah dan penggunaanya mudah.

Variabel yang tidak berpengaruh secara signifikan adalah variabel luas lahan, pupuk kotoran sapi, pupuk ZA, pupuk Phonska, pupuk SP36, pestisida Furadan, Insektisida Abamectin dan Antracol serta insektisida Confidor.

Penggunaan luas lahan dalam usahatani sulit untuk dilakukan penambahan, karena keterbatasan modal dan penggunaan lahan juga diperuntukkan sebagai pemukiman, fasilitas umum dan pengembangan objek wisata tidak murni sebagai lahan pertanian saja, sehingga sulit dilakukan penambahan jumlah lahan.

Pupuk kotoran sapi yang digunakan sebagian berasal dari sapi yang dipelihara petani dan sebagian dibeli. Pupuk kotoran sapi yang baik yakni pupuk kotoran sapi yang telah kering (dijemur terlebih dahulu). Penjemuran yang tidak maksimal menyebabkan pupuk kotoran sapi masih bersifat basah dan panas sehingga kurang baik bagi perakaran tanaman.

Penggunaan pestisida akan bertambah saat terjadinya serangan hebat hama atau penyakit. Penyakit trips (Thrips parvispinus) merupakan penyakit yang paling banyak menyerang tanaman cabai pada musim kemarau (Santika,1995). Penggunaan pestisida secara berlebihan selain menambah biaya produksi juga dapat meningkatkan resisten penyakit terhadap pestisida tertentu. 


\section{EFISIENSI USAHATANI CABAI MERAH}

Efisiensi usahatani cabai merah di lahan pasir pantai Kecamatan Temon dapat diketahui dengan menghitung rasio NPM suatu faktor produksi dengan harga masingmasing faktor produksi (NPMx./Px). Terdapat tujuh variabel yang berpengaruh secara nyata terhadap produksi cabai merah yakni penggunaan benih, tenaga kerja, pupuk kotoran ayam, pupuk NPK Mutiara,fungisida Ampligo, jenis benih dan mulsa.

Efisiensi usahatani akan memenuhi syarat jika faktor produksi berpengaruh secara signifikan dan pemakaiannya pada daerah rasional. Daerah rasional adalah daerah dimana keuntungan maksimum tercapai dan elastisitas produksinya (koefisien regresi) bernilai $1>$ Ep $>0$ (Soekartawi,2003). Variabel benih mempunyai nilai koefisien regresi sebesar 0,25 merupakan satusatunya variabel yang signifikan dan berada di daerah rasional.

TABEL 4. ANALISIS EFISIENSI USAHATANI CABAI MERAH DI LAHAN PASIR PANTAI KECAMATAN TEMON

\begin{tabular}{lllll}
\hline No & Uraian & $\begin{array}{l}\text { Koefisien } \\
\text { Regresi }\end{array}$ & NPMx/Px & t- hitung \\
\hline 1 & Benih & 0,25 & 6,28 & 0,84 \\
2 & Tenaga Kerja & 1,02 & 2,29 & 0,56 \\
3 & Pupuk Kotoran Ayam & $-0,04$ & $-1,69$ & 0,41 \\
4 & Pupuk NPK Mutiara & $-0,02$ & $-1,43$ & 0,30 \\
5 & Fungisida Ampligo & $-0,03$ & $-1,07$ & 0,06 \\
\hline
\end{tabular}

Hasil analisis efisiensi menunjukkan bahwa nilai PMx/Px variabel benih sebesar 6,28 dan t-hitung 0,84< t-tabel 2,42 artinya penggunaan benih pada usahatani cabai merah di lahan pasir pantai sudah efisien dan penggunaanya tidak perlu ditambah atau dikurangi. Harga benih cabai merah ini cukup mahal yaitu Rp 100.000/bungkus, sehingga petani dalam menggunakan benih secara hati-hati agar biaya yang dikeluarkan tidak terlalu tinggi.

\section{KESIMPULAN}

1. Pendapatan usahatani cabai merah di lahan pasir pantai Kecamatan Temon tiap 0,38 ha adalah sebesar Rp 9.278.430 per musim tanam dan keuntungannya sebesar Rp 3.094.504 per musim.

2. Secara bersama-sama faktor produksi luas lahan, benih, tenaga kerja, pupuk kotoran ayam, pupuk kotoran sapi, pupuk ZA, pupuk Phonska, pupuk SP36, pupuk NPK Mutiara, insektisida Furadan, Abamectin $\&$ Confidor, fungisida Antracol \& Ampligo, jenis benih dan penggunaan mulsa berpengaruh terhadap produksi cabai merah di lahan pasir pantai. Secara parsial faktor produksi yang berpengaruh terhadap produksi cabai merah adalah jumlah benih, penggunaan tenaga kerja, pupuk kotoran ayam, pupuk NPK Mutiara, fungisida Ampligo, jenis benih dan penggunaan mulsa.

3. Penggunaan benih pada usahatani cabai merah di lahan pantai sudah efisien.

\section{SARAN}

Kondisi lahan pasir pantai yang miskin unsur hara, sebaiknya petani melakukan pembenahan tanah dengan menambah penggunaan pupuk organik sehingga diharapkan dapat membantu meningkatkan produksi cabai merah. Pupuk organik yang dapat digunakan dalam pembenahan tanah ini antara lain: kotoran ayam, kotoran sapi, kotoran kambing, kotoran burung puyuh.

\section{DAFTAR PUSTAKA}

Gujarati, DN. 2006. Basic Econometrics, third edition. New York: Mc Graw-Hill Inc.

Nazir, M. 2002. Metode Penelitian. Jakarta: Ghalia Indonesia..

Purwantono, D.A 2012. Pengaruh Pembenah Tanah Terhadap Serapan Hara Makro, Kerontokan Daun Dan Hasil Tanaman Cabai Lahan Pasir Pantai Dearah Istimewa Yogyakarta Pada Musim Hujan. Disertasi : Universitas Gadjah Mada Yogyakarta

Rukmana R. 1996. Cabai Hibrida Sistem Mulsa Plastik. Jakarta : Kanisius.

Santika A. 1995. Agribisnis Cabai. Jakarta : Penebar Swadaya.

Soekartawi.2003. Teori Ekonomi Produksi dengan Pokok Bahasan Khusus Analisis Fungsi Cobb - Douglass. Jakarta : PT. Rja Graffindo.

Suratiyah,K. 2006. Ilmu Usahatani. Jakarta: Penebar Swadaya 